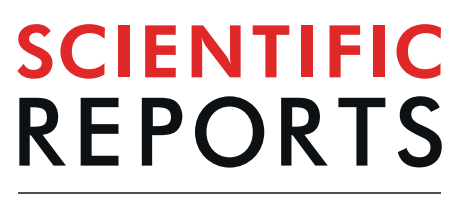

natureresearch

\title{
A potassium chloride to glycine betaine osmoprotectant switch in the extreme halophile Halorhodospira halophila
}

\begin{abstract}
Ratnakar Deole ${ }^{1,2}$ \& Wouter D. Hoff ${ }^{*}$
Halophiles utilize two distinct osmoprotection strategies. The accumulation of organic compatible solutes such as glycine betaine does not perturb the functioning of cytoplasmic components, but represents a large investment of energy and carbon. $\mathrm{KCl}$ is an energetically attractive alternative osmoprotectant, but requires genome-wide modifications to establish a highly acidic proteome. Most extreme halophiles are optimized for the use of one of these two strategies. Here we examine the extremely halophilic Proteobacterium Halorhodospira halophila and report that medium $\mathrm{K}^{+}$ concentration dramatically alters its osmoprotectant use. When grown in hypersaline media containing substantial $\mathrm{K}^{+}$concentrations, $\boldsymbol{H}$. halophila accumulates molar concentrations of $\mathrm{KCl}$. However, at limiting $\mathrm{K}^{+}$concentrations the organism switches to glycine betaine as its major osmoprotectant. In contrast, the closely related organism Halorhodospira halochloris is limited to using compatible solutes. $H$. halophila performs both de novo synthesis and uptake of glycine betaine, matching the biosynthesis and transport systems encoded in its genome. The medium $\mathrm{K}^{+}$concentration $(\sim 10 \mathrm{mM})$ at which the $\mathrm{KCl}$ to glycine betaine osmoprotectant switch in $\mathrm{H}$. halophila occurs is near the $\mathrm{K}^{+}$content of the lake from which it was isolated, supporting an ecological relevance of this osmoprotectant strategy.
\end{abstract}

All halophilic organisms face the risk of cellular dehydration caused by the high osmotic activity of saline environments, and require osmoprotection strategies to survive. Since saline oceans, saline lakes, inland seas, and saline groundwater constitute $\sim 97 \%$ of all water on earth ${ }^{1}$, and salt deposits underlay roughly one quarter of the land on earth ${ }^{2}$, saline and hypersaline environments are of great ecological significance. In addition, salinity has been identified as a major determinant for microbial community composition ${ }^{3}$. Therefore, halophilic adaptations are of general biological interest. Halophilic microorganisms manage to thrive in saline and even hypersaline environments by increasing the osmotic activity of their cytoplasm to match that of the environment. Two types of osmoadaptive strategies are employed by halophiles and extreme halophiles ${ }^{4-7}$ : either the accumulation of molar concentrations of $\mathrm{KCl}$ or the accumulation of organic compounds such as glycine betaine compatible solutes in their cytoplasm ${ }^{8-11}$. Which of these two main osmoprotection strategies an organism utilizes has profound implications for its ecology, physiology, biochemistry, and evolutionary history.

Organic osmolytes do not interfere with the functional properties of cytoplasmic components ${ }^{10,12-14}$, and are thus referred to as compatible solutes. For organisms utilizing this osmoprotection strategy it therefore suffices to accumulate compatible solutes either by uptake from the extracellular medium or by biosynthesis. However, the biosynthesis of molar concentrations of organic osmoprotectants represents a large investment in terms of ATP, reducing equivalents, and carbon ${ }^{5}$. In contrast, high concentrations of $\mathrm{KCl}$ are generally toxic to various cytoplasmic enzymes ${ }^{15}$. In organisms using $\mathrm{KCl}$ as their main osmoprotectant the profile of isoelectric points of the entire proteome is shifted to acidic values ${ }^{16-23}$. Such proteome acidity is believed to allow enzyme function to proceed in the saline cytoplasm ${ }^{19-21,24,25}$, but is thought to require the organism to permanently maintain high levels of cytoplasmic $\mathrm{KCl}$. Once an organism has evolved an acidic proteome, a key advantage is that $\mathrm{KCl}$ is a bioenergetically inexpensive osmoprotectant. Haloarchaea such as Halobacterium salinarum rely almost entirely on $\mathrm{KCl}$, while many halophilic Bacteria predominantly use glycine betaine ${ }^{26,27}$. Almost all halophiles and extreme

${ }^{1}$ Department of Microbiology and Molecular Genetics, Oklahoma State University, Stillwater, Oklahoma, 74078, USA. ${ }^{2}$ Department of Biochemistry and Microbiology at Oklahoma State University-Center for Health Sciences, College of Osteopathic Medicine, Tulsa, Oklahoma, 74464, USA. *email: wouter.hoff@okstate.edu 
halophiles for which osmoprotectant levels have been reported exclusively use either $\mathrm{KCl}$ or compatible solutes as their main osmoprotectants ${ }^{4-6}$. This overarching view that has guided thinking regarding the dual nature of osmoprotection strategies has been challenged by recent experimental results ${ }^{28,29}$, which prompted us to perform the studies reported here.

Most knowledge regarding halophilic osmoprotection strategies has been obtained through extensive studies of a very small number of organisms, particularly the Archaeon Halobacterium salinarum ${ }^{17}$ and Salinibacter ruber (Bacteroidetes) $)^{22,30}$. Therefore, we aimed to examine the osmoprotection strategy of extreme halophiles from other bacterial phyla, and selected two closely related ${ }^{31}$ extremely halophilic purple photosynthetic Proteobacteria: Halorhodospira halophila ${ }^{32}$ and Halorhodospira halochloris ${ }^{33}$. While H. halochloris has been shown to utilize glycine betaine as its main osmoprotectant ${ }^{34}$, we found that $H$. halophila predominantly accumulates molar concentrations of $\mathrm{KCl}^{28}$. This result implies a relatively recent and dramatic evolutionary change in osmoprotection strategy. Unexpectedly, we found that at lower salinity (approximately that of sea water) $H$. halophila retains an acidic proteome but does not accumulate cytoplasmic $\mathrm{KCl}$ beyond levels found in $E$. coli ${ }^{28}$. This observation does not follow the expectation that acidic proteomes in halophiles require high levels of $\mathrm{KCl}$ to be functional. In addition, further studies revealed that many Halobacteriales are not limited to the use of $\mathrm{KCl}$ as their osmoprotectant but utilize organic osmoprotectants ${ }^{29}$. Taken together, these observations imply an unexpected diversity in osmoprotection mechanisms. While most extreme halophiles are believed to dedicate their osmoprotection strategy either to the use of $\mathrm{KCl}$ or organic osmoprotectants, here we report the existence of an "omoprotection switch" in H. halophila, allowing this organism to switch between the $\mathrm{KCl}$ and organic osmoprotectant strategies depending on environmental conditions.

\section{Methods}

Cell growth. H. halophila SL1 and H. halochloris were obtained from DSMZ, Germany, and were grown in DSMZ 253 medium without yeast extract containing various $\mathrm{NaCl}(5-35 \%)$ and $\mathrm{KCl}(0.035$ to $10 \mathrm{~g} / \mathrm{l})$ concentrations. Yeast extract was omitted to avoid possible unknown increases in medium $\mathrm{K}^{+}$concentration and because it contains proline and glycine betaine that can interfere with experiments on osmoadaptation. Anaerobic photosynthetic cell growth was performed in fully filled and closed $20 \mathrm{ml}$ screw cap glass tubes, and monitored through the optical density of the cultures at $660 \mathrm{~nm}$ using an HP8453 diode array spectrophotometer using a custom-made adaptor to hold the glass tubes in place in the measurement beam of the spectrophotometer. It should be noted that the use of optical density introduces some uncertainties, because it is affected by the size and shape of bacteria and by the difference in refractive index between the cells and their medium, and these properties can vary during osmoadaptation. Since our experiments involve the determination of growth curves (typically over three days), our data allow us to verify if the cultures exhibit sustained growth (as detected by a sustained increase in optical density).

Determination of cellular potassium and chloride content. For plasma emission spectrometric determination of cellular $\mathrm{K}^{+}$content, $20 \mathrm{ml}$ of cell culture was centrifuged (3,750 rpm, 25 minutes). Cell pellets were suspended either in isotonic $\mathrm{NaCl}$ solutions or in isotonic ammonium sulfate solutions (to avoid $\mathrm{Cl}^{-}$contamination), again pelleted, and dried for 48 hours at $65^{\circ} \mathrm{C}$. The dried pellets were divided in two halves. One half was used to measure potassium and sodium content using inductively coupled plasma emission spectrometry (Spectro Arcos). The second half was used for colorimetric determination of chloride content using the Lachat 8000 Quick Chem flow injection analyzer ${ }^{35}$. The measurements were performed in triplicates in two independent experiments, for a total of 6 measurements per data point.

To calculate cytoplasmic $\mathrm{K}^{+}$and $\mathrm{Cl}^{-}$concentrations for $H$. halophila and $H$. halochloris, measurements on $E$. coli samples were performed in parallel, and were used as a standard to calibrate the measured $\mathrm{K}^{+}$and $\mathrm{Cl}^{-}$amounts in terms of cytoplasmic concentration. This approach uses the published cytoplasmic $\mathrm{K}^{+}$and $\mathrm{Cl}^{-}$ concentrations of $E$. coli of $211 \mathrm{mM}$ and $188 \mathrm{mM}$, respectively ${ }^{36}$. This method uses the assumption that the cytoplasmic volume of $H$. halophila and $H$. halochloris per OD660 unit is comparable to that of E. coli. Previously we have reported evidence that the accuracy of this approximation is sufficient to obtain physiologically relevant insights into osmoadaptation by $H$. halophila ${ }^{28}$. It should be noted that errors in value of the cytoplasmic volume of $\mathrm{H}$. halophila used here will result in the same systematic error in the absolute concentrations of $\mathrm{K}+, \mathrm{Cl}-$, and glycine betaine, and will therefore not affect the main conclusion reported here regarding the existence of a potassium chloride to glycine betaine osmoprotectant switch in this organism.

Determination of cellular glycine betaine content. Glycine betaine determinations were performed based on published methods ${ }^{37}$ ( $\mathrm{see}^{38}$ for validation of this method). $100 \mathrm{ml}$ cultures of $H$. halochloris and $H$. halophila cells were harvested in the late exponential phase. Cells were washed using isotonic $\mathrm{NaCl}$ solutions and freeze-thawed at $-4^{\circ} \mathrm{C}$ for 30 minutes to promote cell lysis. The cells were then diluted in distilled water $(0.1 \mathrm{mg}$ cells $/ \mathrm{ml})$ in the presence of lysozyme $(1 \mathrm{mg} / \mathrm{ml}) .10 \%(\mathrm{w} / \mathrm{v})$ of $0.2 \mathrm{~N}$ perchloric acid was added and the $\mathrm{pH}$ adjusted to 7 using a $0.1 \mathrm{~N} \mathrm{NaOH}$ solution. The resulting cell free extract was passed through the weakly cationic resin Amberlite CG-50 for chromatographic extraction of glycine betaine. The column was eluted with phosphate-citrate buffer $\mathrm{pH} 5.3 .1 .5 \mathrm{ml}$ of $2 \mathrm{~N} \mathrm{HCl}$ was added to each $0.5 \mathrm{ml}$ fraction collected from this column. $1 \mathrm{ml}$ of reagent $(10 \mathrm{~g}$ iodine $+12.4 \mathrm{~g} \mathrm{KI}$ per $100 \mathrm{ml})$ was then added to convert glycine betaine to its periodide derivative, which has an absorption maximum at $365 \mathrm{~nm}$. The solution was shaken and placed on ice for $20 \mathrm{~min}$. $10 \mathrm{ml}$ of 1,2 dichloroethane was added followed by thorough mixing. The absorbance of the organic (lower) layer was measured at $365 \mathrm{~nm}$ using a Cary 300 spectrophotometer and compared to standard curves of pure glycine betaine between $10 \mathrm{mM}$ to $2000 \mathrm{mM}$. The cytoplasmic concentration of glycine betaine of $H$. halophila was determined using $H$. halochloris samples grown in $4 \mathrm{M} \mathrm{NaCl}$, which have been reported to contain a cytoplasmic glycine betaine concentration of $1.6 \mathrm{M}^{34}$. 

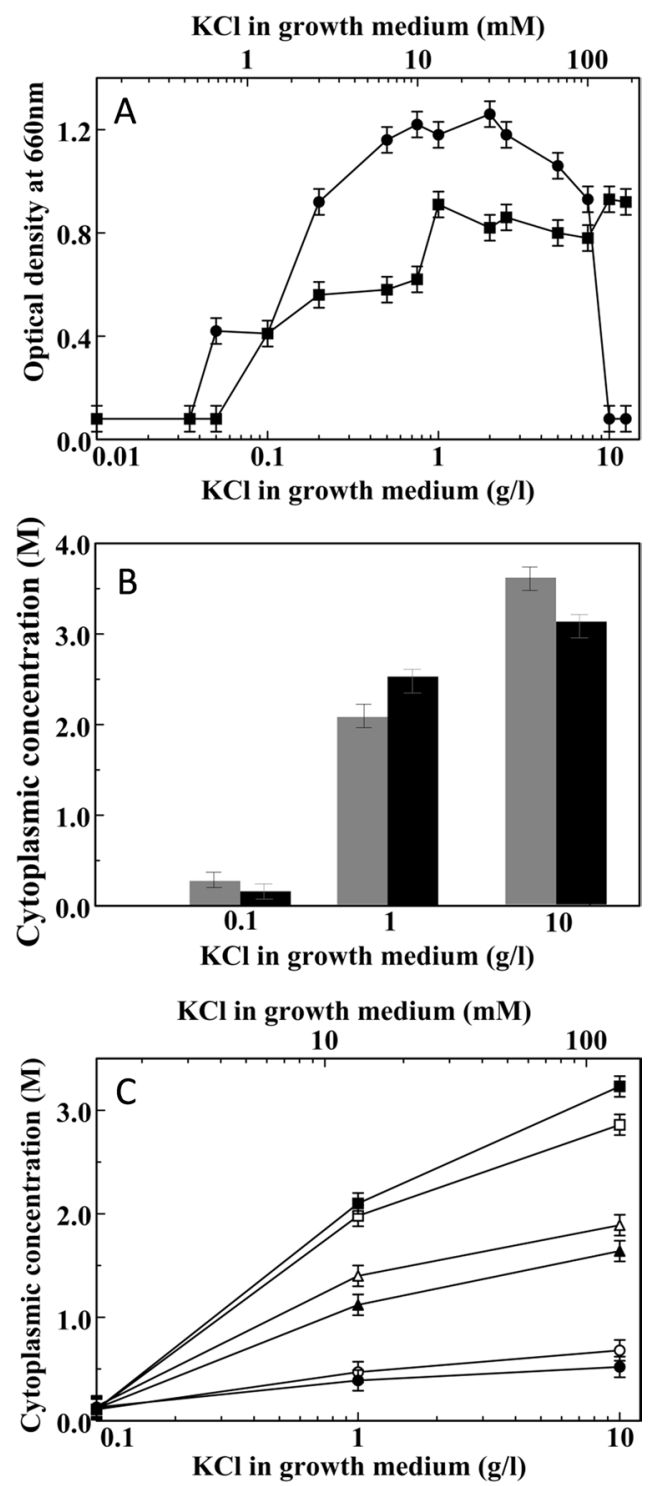

Figure 1. Potassium limitation prevents $\mathrm{KCl}$ accumulation by Halorhodospira halophila. (A) Dependence of the final optical density of $\mathrm{H}$. halophila cultures grown at $5 \%$ (circles) or $35 \%$ (squares) $\mathrm{NaCl}$ on $\mathrm{KCl}$ concentration in the growth medium. (B) Cytoplasmic $\mathrm{K}^{+}$(black bars) and $\mathrm{Cl}^{-}$(gray bars) concentrations in H. halophila grown in $35 \% \mathrm{NaCl}$ in the presence of $0.1,1$, and $10 \mathrm{~g} / \mathrm{KCl}$. (C) Effect of growth medium $\mathrm{KCl}$ content on cytoplasmic $\mathrm{K}^{+}$(open symbols) and $\mathrm{Cl}^{-}$(closed symbols) concentrations for cells grown in the presence of $35 \%$ (squares), 15\% (triangles), and 5\% (circles) $\mathrm{NaCl}$.

\section{Results and Discussion}

Potassium limitation prevents the use of $\mathrm{KCl}$ as the main osmoprotectant in $\mathrm{H}$. halophile. Since $H$. halophila utilizes $\mathrm{KCl}$ as a main osmoprotectant ${ }^{28}$, we were interested to examine if reducing $\mathrm{K}^{+}$concentration in the growth medium impedes this strategy. To determine the $\mathrm{K}^{+}$requirement for growth at 5 and $35 \% \mathrm{NaCl}$, cell growth was measured in media containing a range of $\mathrm{K}^{+}$concentrations. The expectation for these experiments was that at higher medium salinity $H$. halophila would have a higher requirement for $\mathrm{K}^{+}$, and that limiting $\mathrm{K}^{+}$ availability would reduce cell growth. Unexpectedly, we observed that for cells grown in media of low salinity, high $\mathrm{K}^{+}$concentrations inhibit growth (Fig. 1A). This cytotoxic effect of high $\mathrm{K}^{+}$concentrations was not observed for cells grown in highly saline media $(35 \% \mathrm{NaCl})$, and may be caused by osmotic misregulation. Upon lowering medium $\mathrm{K}^{+}$concentrations, cell growth was largely unaffected down to $0.05 \mathrm{~g} / \mathrm{KCl}(0.7 \mathrm{mM})$, but was completely inhibited at $\sim 0.02 \mathrm{~g} / \mathrm{l}(0.3 \mathrm{mM})$ (Fig. 1A). In comparison, the growth of Halobacterium salinarum is impaired when the medium $\mathrm{K}^{+}$concentration is reduced to below $3 \mathrm{mM}^{39}$. The $\mathrm{K}^{+}$requirement for growth of $H$. halophila at $35 \% \mathrm{NaCl}$ is only slightly higher than for growth in $5 \% \mathrm{NaCl}$ (Fig. 1A).

Based on these experiments we selected conditions to examine the effect of growth medium $\mathrm{K}^{+}$concentration on cytoplasmic $\mathrm{KCl}$ accumulation. We osmotically challenged $H$. halophila by growth in media containing $35 \% \mathrm{NaCl}$ and varied $\mathrm{K}^{+}$concentration from the lowest values that permit substantial cell growth $(0.1 \mathrm{~g} / \mathrm{KCl})$, to standard $\mathrm{K}^{+}$concentration $(1 \mathrm{~g} / \mathrm{l} \mathrm{KCl})$ and high $\mathrm{K}^{+}$concentration $(10 \mathrm{~g} / \mathrm{l} \mathrm{KCl})$. Inductively coupled plasma 

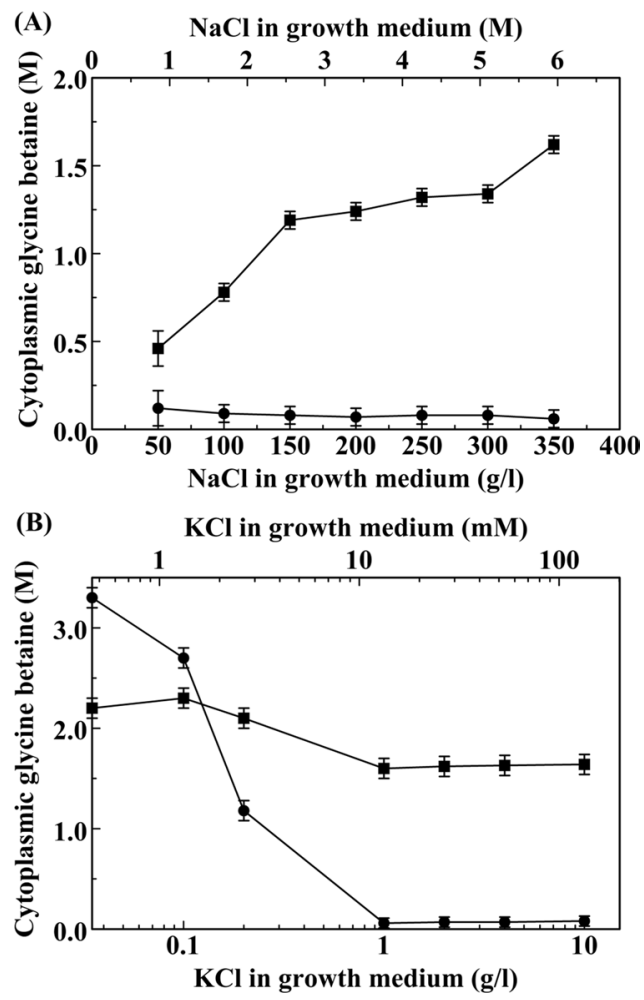

Figure 2. Dependence of glycine betaine biosynthesis in Halorhodospira halophila (circles) and Halorhodospira halochloris (squares) on growth medium salinity and $\mathrm{K}^{+}$concentration. (A) Effect of growth medium $\mathrm{NaCl}$ concentration on cytoplasmic glycine betaine concentrations of cells grown in media containing $1 \mathrm{~g} / \mathrm{KCl}$. (B) Effect of growth medium $\mathrm{KCl}$ concentration on cytoplasmic glycine betaine concentrations of cells grown in media containing $35 \% \mathrm{NaCl}$.

emission spectrometry measurements revealed high cytoplasmic $\mathrm{K}^{+}$concentrations (up to $3.2 \mathrm{M}$ ) in cells grown at or above $1 \mathrm{~g} / \mathrm{l} \mathrm{KCl}$ in the growth medium (Fig. 1B). However, when growth medium $\mathrm{KCl}$ concentrations were reduced to $0.1 \mathrm{~g} / \mathrm{l}$, the cytoplasmic $\mathrm{K}^{+}$concentration dropped sharply to $\sim 0.1 \mathrm{M}$. Colorimetric assays to determine cellular $\mathrm{Cl}^{-}$levels revealed a very similar pattern for the cytoplasmic $\mathrm{Cl}^{-}$concentration, which ranged from $3.6 \mathrm{M}$ at high medium $\mathrm{K}^{+}$concentration to $\sim 0.1 \mathrm{M}$ at low medium $\mathrm{K}^{+}$concentration (Fig. 1B).

Since medium salinity in our experiments is largely determined by the presence of $\mathrm{NaCl}$, all growth conditions tested offer plentiful $\mathrm{Cl}^{-}$. The observation that low medium $\mathrm{K}^{+}$concentrations result in a parallel reduction not only of cytoplasmic $\mathrm{K}^{+}$but also cytoplasmic $\mathrm{Cl}^{-}$concentrations points to the need to maintain overall cytoplasmic electroneutrality, and implies that the main cytoplasmic counterion for $\mathrm{Cl}^{-}$in $\mathrm{H}$. halophila is $\mathrm{K}^{+}$. Since the growth media contain $35 \% \mathrm{NaCl}\left(6 \mathrm{M} \mathrm{Cl}^{-}\right)$, these cells experience a considerable transmembrane $\mathrm{Cl}^{-}$gradient.

The reduction in cellular $\mathrm{KCl}$ content upon lowering the $\mathrm{K}^{+}$concentration of the growth medium was most prominent in cells grown at high $\mathrm{NaCl}$ concentrations, where cells were most osmotically challenged. At lower $\mathrm{NaCl}$ concentrations a similar trend was observed (Fig. 1C), but maximal cellular $\mathrm{KCl}$ levels were lower, in line with the reduced salinity of the growth medium. Taken together, these experiments reveal that growth at $\mathrm{K}^{+}$concentrations below $\sim 10 \mathrm{mM}$ inhibits cellular $\mathrm{KCl}$ accumulation by $H$. halophila.

Cells grown in media containing high $\mathrm{NaCl}$ concentrations (35\%) but low $\mathrm{K}^{+}$levels require a cytoplasmic osmoprotectant to avoid cytoplasmic dehydration. The data depicted in Fig. 1 demonstrate that under these growth conditions cells accumulate only $\sim 0.1 \mathrm{M} \mathrm{KCl}$ despite growing in $6 \mathrm{M} \mathrm{NaCl}$. Apparently, an osmoprotectant other than $\mathrm{KCl}$ is involved. Interestingly, $H$. halochloris is closely related to $H$. halophila ${ }^{31}$ but utilizes glycine betaine as its main osmoprotectant ${ }^{34}$. Therefore, we examined the glycine betaine content of $H$. halophila cells.

Regulation of glycine betaine biosynthesis by medium $\mathrm{KCl}$ concentration is strikingly different in $\boldsymbol{H}$. halophila and $\boldsymbol{H}$. halochloris. We used a colorimetric assay to measure the effect of medium salinity and $\mathrm{K}^{+}$ concentration on cytoplasmic glycine betaine concentration in both $H$. halochloris, which accumulates molar concentrations of this organic osmoprotectant ${ }^{34}$, and H. halophila, which is known to accumulate molar concentrations of $\mathrm{KCl}^{28}$. For $\mathrm{H}$. halochloris grown at $1 \mathrm{~g} / \mathrm{l} \mathrm{KCl}$, these experiments confirmed the presence of high levels of glycine betaine for cells grown in highly saline media (Fig. 2A). Decreasing the medium NaCl concentration from $35 \%$ to $5 \%$ reduced cytoplasmic glycine betaine concentration from $1.7 \mathrm{M}$ to $0.4 \mathrm{M}$ in this organism (Fig. 2A). In contrast, under these growth conditions $H$. halophila cells contain only $\sim 0.16 \mathrm{M}$ of glycine betaine, even at $35 \% \mathrm{NaCl}$. This result reveals a striking difference in the osmoprotection strategy utilized by these closely related organisms. Since the cytoplasmic $\mathrm{KCl}$ content of $H$. halophila is greatly reduced upon growth in media containing $0.1 \mathrm{~g} / \mathrm{l} \mathrm{KCl}$ (Fig. 1B,C), we investigated if under these low $\mathrm{K}^{+}$conditions this organism produces glycine betaine. 


\begin{tabular}{|c|c|c|c|}
\hline Function & H. halophila gene & $\begin{array}{l}\text { Organism containing most } \\
\text { closely related gene* }\end{array}$ & Sequence identity \\
\hline \multicolumn{4}{|l|}{ Glycine betaine biosynthesis } \\
\hline \multicolumn{4}{|l|}{ Biosynthesis from glycine } \\
\hline Methyltransferase I & WP_011814464 & H. halochloris & $90 \%$ \\
\hline Methyltransferase II & WP_011814463 & H. halochloris & $73 \%$ \\
\hline \multicolumn{4}{|l|}{ Biosynthesis from choline } \\
\hline Choline dehydrogenase & None & NA & NA \\
\hline Betaine aldehyde dehydrogenase & None & NA & NA \\
\hline Choline oxidase & None & NA & NA \\
\hline \multicolumn{4}{|l|}{ Glycine betaine transporters } \\
\hline \multicolumn{4}{|c|}{ Transporters from the ABC superfamily } \\
\hline OpuA & WP_081432241 & Lactococcus lactis & $55 \%$ \\
\hline OpuA & WP_011813050 & Bacillus subtilis & $33 \%$ \\
\hline \multicolumn{4}{|c|}{ Transporters from the BCCT family } \\
\hline BetU & WP_011815149 & Escherichia coli & $49 \%$ \\
\hline BetH & WP_011814173 & Halobacillus trueperi & $46 \%$ \\
\hline BetL & WP_011814637 & Listeria monocytogenes & $40 \%$ \\
\hline OpuD & WP_011813054 & Bacillus subtilis & $43 \%$ \\
\hline BetL & WP_011813152 & Listeria monocytogenes & $34 \%$ \\
\hline \multicolumn{4}{|c|}{ Transporters from the MFS superfamily } \\
\hline OusA & None & NA & NA \\
\hline ProP & None & NA & NA \\
\hline
\end{tabular}

Table 1. Analysis of the genome of $H$. halophila for the presence of genes involved in the biosynthesis and transport of glycine betaine. *The transporter that showed the highest level of sequence identity to the indicated gene from the $H$. halophila genome is shown.

$H$. halophila and $H$. halochloris cells were grown at $35 \% \mathrm{NaCl}$ and a range of growth medium $\mathrm{K}^{+}$concentrations. Colorimetric measurements of the resulting cell extracts revealed that the glycine betaine content of $H$. halochloris depends only slightly on medium $\mathrm{K}^{+}$concentration, with an increase from $1.64 \mathrm{M}$ to $2.2 \mathrm{M}$ upon a reduction in medium $\mathrm{K}^{+}$concentration from $10 \mathrm{~g} / \mathrm{l} \mathrm{KCl}$ to $0.035 \mathrm{~g} / \mathrm{K} \mathrm{KCl}$ (Fig. 2B). For H. halophila the same decrease in medium $\mathrm{K}^{+}$concentration causes a dramatic increase in cytoplasmic glycine betaine concentration from $0.1 \mathrm{M}$ to $3.3 \mathrm{M}$ (Fig. 2B). The midpoint for this induction of glycine betaine biosynthesis occurs near $10 \mathrm{mM} \mathrm{K}^{+}$. These experiments show that $H$. halophila switches its main osmoprotectant from $\mathrm{KCl}$ to glycine betaine upon growth in media containing low $\mathrm{K}^{+}$concentrations. For H. halochloris such an osmoprotectant switch is not observed; this organism accumulates glycine betaine but not $\mathrm{K}^{+}$. These results are in line with the stark difference in proteome acidity between these two organisms: where $H$. halophila exhibits the proteome acidity that is associated with $\mathrm{K}^{+}$accumulation, the proteome of $H$. halochloris does not ${ }^{28}$.

Genomic potential of $\boldsymbol{H}$. halophila for biosynthesis and uptake of glycine betaine. The availability of the $H$. halophila genome ${ }^{40}$ allows a search for genes likely to be involved in its osmoprotectant strategy. Previously, we reported that its genome encodes multiple $\mathrm{K}^{+}$transporters, in line with its capability to accumulate $\mathrm{K}^{+28}$. In view of the ability of $H$. halophila to utilize glycine betaine as an osmoprotectant reported here, we examined its genome for the presence of genes involved in this capability.

To investigate the genomic potential of $H$. halophila for both the biosynthesis and the uptake of glycine betaine, we performed a series of homology searches for the range of enzymes reported to perform these functions in a range of bacteria. Microorganisms can use variety of routes to increase intracellular glycine betaine concentrations. Glycine betaine can either be biosynthesized or it can be taken up from the external environment. For biosynthesis of glycine betaine either choline or amino acid glycine can be used as a precursor. Choline uptake from exogenous sources is energetically more favorable than its de novo synthesis, and bacteria can use ATP-binding cassette $(\mathrm{ABC})$ transporters or secondary transporters for its uptake. Two choline uptake systems are known in E. coli: the ABC transporter ProU and the proton motive force-driven, high-affinity uptake system BetT. At low external concentrations, choline is mainly taken up by BetT, whereas at higher concentrations choline is also transported by ProU ${ }^{41}$. In Bacillus subtilis, two closely related high-affinity ABC transport systems, $\mathrm{OpuB}$ and $\mathrm{OpuC}$, have been identified ${ }^{42}$. OpuC transports a variety of osmoprotectants, whereas OpuB is specific for choline ${ }^{43}$. Soil bacteria, specifically Arthrobacter globiformis and Arthrobacter panescens, synthesize glycine betaine by one step oxidation of choline by enzyme, choline oxidase with hydrogen peroxide as a byproduct ${ }^{44,45}$. In Escherichia coli glycine betaine is synthesized by choline dehydrogenase (CDH) and BADH with the similar betaine aldehyde as an intermediate product ${ }^{46}$. In Bacillus subtilis intracellular choline is converted to glycine betaine using two enzymes, glycine betaine aldehyde dehydrogenase (GsbA) and type-III alcohol dehydrogenase (GbsB). These enzymes are encoded by gbsAB operon ${ }^{47}$.

Actinopolyspora halophila and H. halochloris, two extremely halophilic bacteria, synthesize glycine betaine through a distinct de novo pathway that uses glycine as a precursor, via a three-step methylation process in 


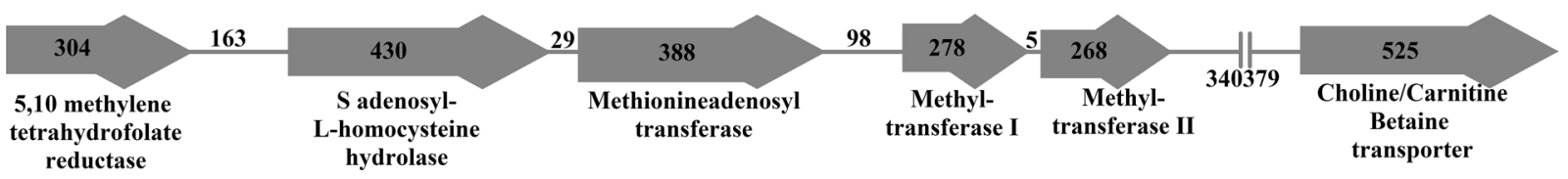

Figure 3. Bioinformatics of glycine betaine biosynthesis and uptake in Halorhodospira halophila. The likely operon encoding genes involved in tetrahydrofolate (THF) metabolism and two methyltransferases for the biosynthesis of glycine betaine from glycine are depicted together with the gene encoding a glycine betaine transporter that is located far downstream. The number of encoded amino acids and the number of bases separating the genes are indicated. The sequence similarities of the two depicted methyltransferases and transporter are listed in Table 1.

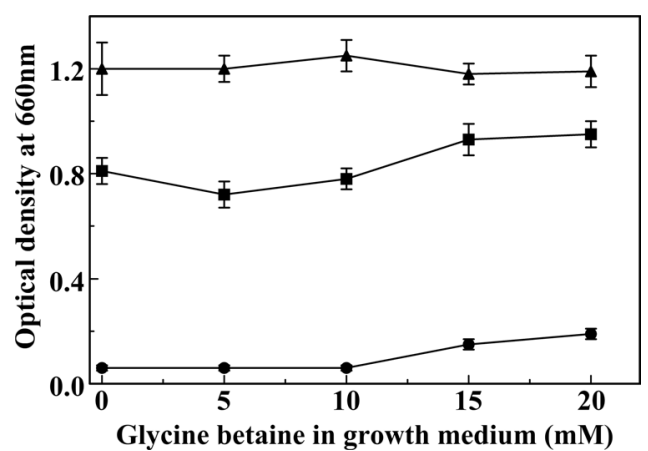

Figure 4. Extracellular glycine betaine stimulates $H$. halophila cell growth at low $\mathrm{K}^{+}$concentrations. The final optical density of cell cultures were determined after 72 hours of growth in the presence of 0.02 (circles), 0.4 (squares), and $1.0 \mathrm{~g} / \mathrm{l}$ (triangles) $\mathrm{KCl}$ in media containing $35 \% \mathrm{NaCl}$.

which S-adenosylmethionine (SAM) serves as the methyl donor. The enzymes involved, glycine sarcosine $\mathrm{N}$-methyltransferase (GSMT) and sarcosine dimethylglycine N-methyltransferase (SDMT), produce the intermediates sarcosine and dimethylglycine and the end product, glycine betaine ${ }^{48}$.

Glycine betaine transporters can be ATP-driven or driven by secondary ion gradients, and belong to three different large families of transporters: (1) ABC transporters (such as ProU from E. coli and OpuA from Lactococcus lactis), (ii) transporters from the betaine/carnitine/choline transporter (BCCT) family (for example BetP from Corynebacterium glutamicum ${ }^{49}$, and (3) major facilitator superfamily (MFS family), see ${ }^{50}$.

Homology searches for related proteins encoded in the genome of $H$. halophila yielded the following insight (Table 1, also see Supplemental Table 1). With respect to the biosynthesis of glycine betaine, clear homologs were found in the H. halophila genome for the two methyltransferases involved in the pathway starting from glycine (Fig. 3; Table 1). The sequences of the glycine-sarcosine methyltransferases and the sarcosine-dimethylglycine methyltransferases from Halorhodospira halochloris ${ }^{48}$ and from the actinomycete Actinopolyspora halophila ${ }^{51}$ are highly similar to the corresponding proteins in $H$. halophila (H_hal1677 and H_hal1678) (in the range 72 to $90 \%$ sequence identity over the entire length of the protein. These genes appear to be part of the same operon (Fig. 3). Interestingly, immediately upstream of the genes encoding the two methyltransferases are three genes involved in tetrahydrofolate (THF) metabolism. This genetic association suggests that a substantial portion of the methyl groups donated by THF are utilized in $H$. halophila for the biosynthesis of glycine betaine. The presence of this gene cluster in the H. halophila genome matches its experimentally observed (Fig. 2) biosynthesis of glycine betaine and provides clear candidates for the genes in the $H$. halophila genome that encode the enzymes for glycine betaine synthesis from glycine. No homologs were found in the H. halophila genome for other possible biosynthetic routes for glycine betaine.

With respect to the uptake of glycine betaine from the medium through transport systems, the H. halophila genome contains seven different genes with clear sequence similarity to relevant transport proteins. Two of these genes are from the $\mathrm{ABC}$ superfamily of transporters, and exhibit substantial sequence similarity to OpuA from Lactobacillus lactis (55\% sequence identity) and OpuA from B. subtilis (33\% sequence identity), respectively. The remaining five genes showed substantial sequence identify (from $34 \%$ to $49 \%$ ) sequence identity with various glycine betaine transporters from the BCCT family (Table 1). No candidate glycine betaine transporters from the MFS superfamily were identified. Further studies will be needed to test if these seven genes indeed encode transporters for glycine betaine. Taken together, these results suggest that $H$. halophila is capable not only of glycine betaine biosynthesis, but also of its uptake from the growth medium.

To explore the predicted capacity for glycine betaine uptake by $H$. halophila, we grew the cells at $35 \% \mathrm{NaCl}$ in the presence of low $\mathrm{K}^{+}$concentrations. These are conditions under which the cells accumulate glycine betaine and therefore would be predicted to benefit from uptake of this compatible solute from the growth medium. Indeed, at reduced $\mathrm{K}^{+}$concentrations that hamper the use of $\mathrm{KCl}$ as the main osmoprotectant $(0.4$ and $0.02 \mathrm{~g} / \mathrm{KCl})$, the addition of 15 or $20 \mathrm{mM}$ glycine betaine to the growth medium results in a modest increase in the final OD of the 


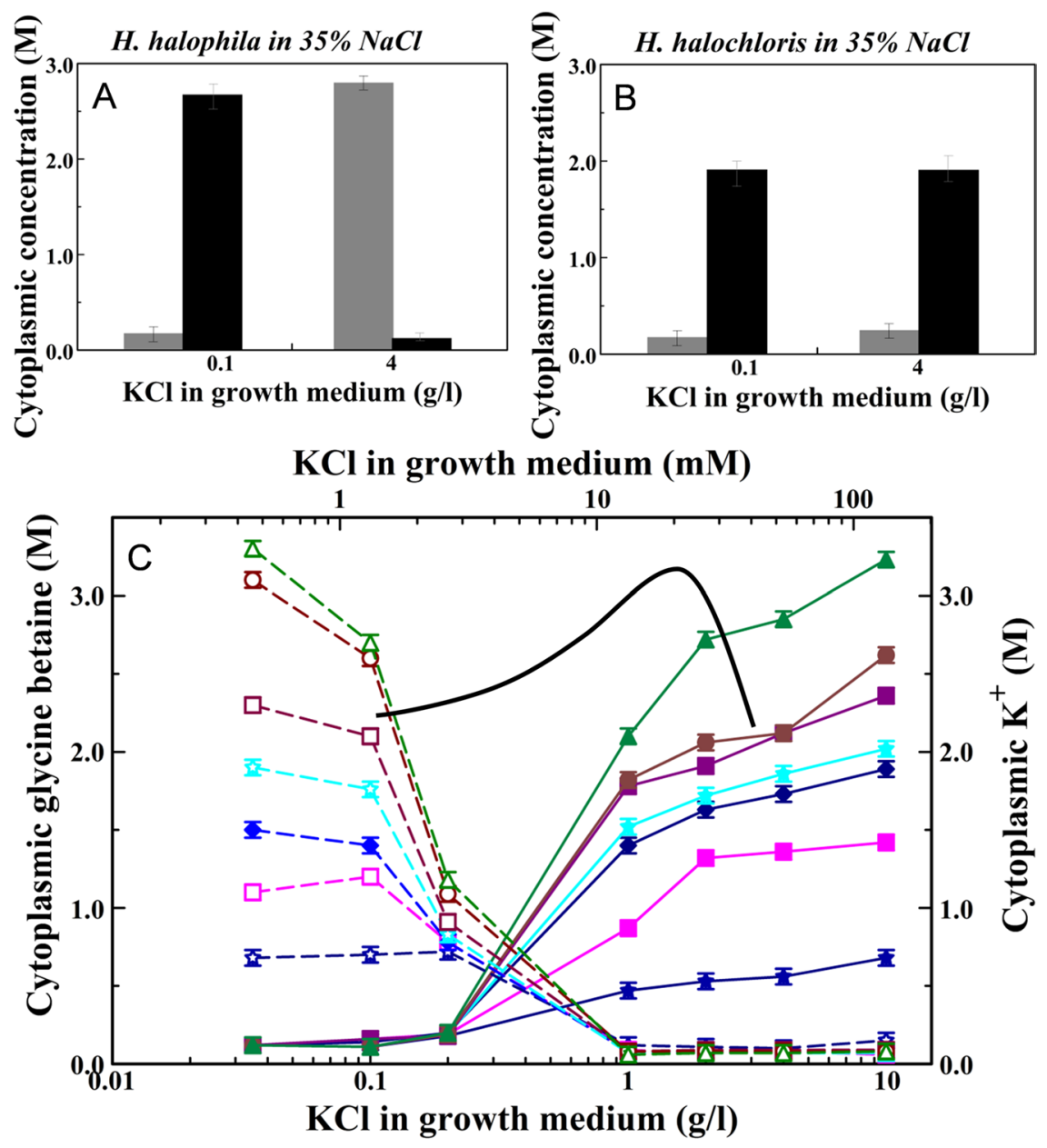

Figure 5. A potassium chloride to glycine betaine osmoprotection switch in Halorhodospira halophila. Cytoplasmic $\mathrm{K}^{+}$(gray bars) and glycine betaine (black bars) concentrations of $H$. halophila (A) and $H$. halochloris (B) grown media containing $35 \% \mathrm{NaCl}$ and at 0.1 and $4 \mathrm{~g} / \mathrm{KCl}$. (C) The effect of growth medium $\mathrm{KCl}$ content on cytoplasmic glycine betaine (closed symbols and dotted lines) and $\mathrm{K}^{+}$(open symbols and solid lines) concentrations for $\mathrm{H}$. halophila cells growth at various $\mathrm{NaCl}$ concentrations: $5 \%$ (dark blue diamonds), $10 \%$ (pink squares), 15\% (dark blue diamonds), 20\% (light blue stars), 25\% (purple squares), 30\% (brown circles), and 35\% (green triangles). The average and standard deviation for the $\mathrm{KCl}$ content of 6 Wadi Natrun lakes is indicated as a Gaussian curve.

cultures (Fig. 4). This observation supports the possibility that $H$. halophila can acquire glycine betaine both by de novo biosynthesis and by uptake from the growth medium. However, previous cases in which glycine betaine uptake was an effective part of microbial osmoprotection, glycine betaine concentrations in the growth medium in the micromolar to $1 \mathrm{mM}$ range were found to be effective ${ }^{14,52}$. These considerations indicate that externally provided glycine betaine does not function as an effective osmoprotectant in H. halophila.

The natural habitat of $H$. halophila is hypersaline lakes ${ }^{32,53,54}$. It is therefore not immediately obvious how $H$. halophila would encounter environments in which glycine betaine would be available for uptake. Interestingly, when $H$. halochloris and the related organism Ectothiorhodospira marismortui are exposed to a sudden drop in medium salinity, as would be encountered in nature after rain causes a sudden influx of fresh water, the cells respond by secreting glycine betaine into the medium ${ }^{26,55,56}$. This glycine betaine can subsequently be taken up by the cells ${ }^{57}$. The presence of a glycine betaine transporter in the genome of $H$. halophila suggests the possibility that a similar mechanism operates in this organism. A related physiological role for glycine betaine uptake is that upon their biosynthesis, a substantial fraction of compatible solute molecules can be released into the growth medium and appears to be recycled via uptake systems, increasing the efficiency of their usage ${ }^{58}$.

A potassium chloride to glycine betaine osmoprotectant switch. The data reported in Figs. 1C and $2 \mathrm{~B}$ indicate that growth medium $\mathrm{K}^{+}$concentration has opposite effects on the use of glycine betaine and $\mathrm{KCl}$ as osmoprotectants in $H$. halophila. When $\mathrm{K}^{+}$is present at sufficient levels in the growth medium, the cells contain high levels of both $\mathrm{K}^{+}$and $\mathrm{Cl}^{-}$, while the biosynthesis and uptake of glycine betaine are reduced to low levels. At low medium $\mathrm{K}^{+}$the opposite effect is observed: cytoplasmic $\mathrm{K}^{+}$and $\mathrm{Cl}^{-}$concentrations are greatly reduced while high levels of glycine betaine biosynthesis are detected (Fig. 2B), together with modest glycine betaine uptake (Fig. 4). 
We systematically studied this effect of medium $\mathrm{K}^{+}$concentration on osmoprotectant use at a wide range of medium $\mathrm{NaCl}$ concentrations (Fig. 5). These experiments show that below $1 \mathrm{~g} / \mathrm{l} \mathrm{KCl}$ cells use glycine betaine but not $\mathrm{K}^{+}$as a main osmoprotectant, while above $1 \mathrm{~g} / \mathrm{KCl}$ the opposite occurs. Thus, near $1 \mathrm{~g} / \mathrm{KCl}$ in the growth medium $H$. halophila exhibits a $\mathrm{KCl}$ to glycine betaine osmoprotectant switch.

To examine the possible physiological relevance of this osmoprotectant switch, we considered the range of ecologically relevant $\mathrm{KCl}$ concentrations that $H$. halophila typically encounters in its natural habitat. For six different Wadi Natrun lakes, in which $H$. halophila thrives ${ }^{53}$, geochemical data have been reported ${ }^{59}$. Interestingly, the average $\mathrm{KCl}$ concentration reported for these lakes varies considerably, but on average is close to $1 \mathrm{~g} / \mathrm{l} \mathrm{KCl}$ (Fig. 5). Therefore, depending on the particular Wadi Natrun lake which $H$. halophila finds itself in, it will be exposed to either sufficient $\mathrm{K}^{+}$, allowing cellular $\mathrm{KCl}$ accumulation, or inadequate levels of $\mathrm{K}^{+}$, necessitating the use of glycine betaine as its main osmoprotectant. This analysis implies that the osmoprotectant switch reported here may well be of ecological relevance for $H$. halophila.

Most extreme halophiles for which the osmoprotection strategy has been studied appear to be specialized in the use of either $\mathrm{KCl}$ or compatible solutes as their main osmoprotectants ${ }^{4-6}$. Two notable exceptions to this pattern are the extremely halophilic methanogen Methanohalophilus strain Z7302, which accumulates molar concentrations of both glycine betaine and $\mathrm{K}^{+}$when grown in hypersaline media ${ }^{60}$, and Natronococcus occultus, an organism that combines the use of $\mathrm{K}^{+}$and 2-sulfotrehalose ${ }^{61}$. A novel aspect of the results reported here is that $H$. halophila is capable of switching between $\mathrm{KCl}$ and glycine betaine as its main osmoprotectants. Some halophiles exhibit an osmoprotectant switch between different organic osmolotes. Under nitrogen limitation $H$. halochloris reduces its ectoine content and increases its use of trehalose as an osmoprotectant ${ }^{62}$. The moderate halophile Halobacillus halophilus switches between different organic osmolytes, including glutamate, glutamine, proline, and ectoine depending on medium salinity and growth phase ${ }^{63,64}$. The osmoprotectant switch reported here for $H$. halophila extends this concept to include the biochemically drastic transition between the two major types of osmoprotectants: $\mathrm{KCl}$ and compatible solutes. This increased physiological flexibility of $H$. halophila allows it to utilize the bioenergetically favorable osmoprotectant $\mathrm{KCl}$ when conditions allow, while maintaining the capacity to grow in hypersaline media depleted in $\mathrm{K}^{+}$.

Observations reported for two other extreme halophiles suggest flexibility in osmoprotectant use depending on medium $\mathrm{K}^{+}$concentrations. In the case of Halobacterium salinarum grown at $25 \mathrm{~g} / \mathrm{l} \mathrm{NaCl}$ a reduction in growth medium $\mathrm{KCl}$ concentration from $100 \mathrm{mM}$ to $3 \mathrm{mM}$ causes a reduction in cytoplasmic $\mathrm{K}^{+}$concentration from $4.0 \mathrm{M}$ to $2.8 \mathrm{M}^{39}$. Thus, both $H$. salinarum and $H$. halophila respond to $\mathrm{K}^{+}$limitation by reducing their cytoplasmic $\mathrm{K}^{+}$concentration. However, in $H$. halophila this response is much stronger, resulting in a more than 10 -fold reduction in cytoplasmic $\mathrm{K}^{+}$content of cells (Fig. 1B,C). For H. halophila we found that under these conditions the role of $\mathrm{KCl}$ as an osmoprotectant is largely taken over by glycine betaine. In the case of H. salinarum it is not known which osmoprotectant compensates for the reduced cytoplasmic $\mathrm{K}^{+}$concent. In this respect it is interesting that $H$. salinarum exhibits chemotaxis responses to various compatible solutes ${ }^{65}$. Secondly, Salinibacter ruber was found to contain molar concentrations of $\mathrm{KCl}$ in combination with low levels of glycine betaine when grown in media containing high $\mathrm{KCl}$ concentrations $(5 \mathrm{~g} / \mathrm{l})^{30}$. The presence of low levels of glycine betaine in this organism suggests the possibility that upon $\mathrm{K}^{+}$starvation it may increase its reliance on this compatible solute. Thus, the osmoprotectant switch reported here for $H$. halophila may be more widespread, as is supported by recent results indicating that the use of organic osmoprotectants is widespread in the Halobacteriales ${ }^{29}$.

Received: 12 September 2019; Accepted: 10 December 2019;

Published online: 25 February 2020

\section{References}

1. Jackson, R. B. et al. Water in a changing world. Ecological Applications 11, 1027-1045, https://doi.org/10.2307/3061010 (2001).

2. McGenity, T. J., Gemmell, R. T., Grant, W. D. \& Stan-Lotter, H. Origins of halophilic microorganisms in ancient salt deposits. Environmental Microbiology 2, 243-250, https://doi.org/10.1046/j.1462-2920.2000.00105.x (2000).

3. Lozupone, C. A. \& Knight, R. Global patterns in bacterial diversity. Proceedings of the National Academy of Sciences of the United States of America 104, 11436-11440, https://doi.org/10.1073/pnas.0611525104 (2007).

4. Grant, W. D. Life at low water activity. Philosophical Transactions of the Royal Society of London Series B-Biological Sciences 359, 1249-1266, https://doi.org/10.1098/rstb.2004.1502 (2004).

5. Oren, A. Bioenergetic aspects of halophilism. Microbiology and Molecular Biology Reviews 63, 334-348 (1999).

6. Oren, A. Microbial life at high salt concentrations: phylogenetic and metabolic diversity. Saline Systems 4, 2, https://doi.org/10.1111/ j.1462-2920.2010.02365.x (2008).

7. Gunde-Cimerman, N., Plemenitaš, A. \& Oren, A. Strategies of adaptation of microorganisms of the three domains of life to high salt concentrations. FEMS Microbiology Reviews 42, 353-375, https://doi.org/10.1093/femsre/fuy009 (2018).

8. Empadinhas, N. \& da Costa, M. S. Osmoadaptation mechanisms in prokaryotes: distribution of compatible solutes. International Microbiology 11, 151-161, https://doi.org/10.2436/20.1501.01.55 (2008).

9. Galinski, E. A. Compatible solutes in halophilic eubacteria: Molecular principles, water-solute interactions, stress protection. Experientia 49, 487-496 (1993).

10. Roberts, M. F. Organic compatible solutes of halotolerant and halophilic microorganisms. Saline Systems 1, 5 (2005).

11. Sleator, R. D. \& Hill, C. Bacterial osmoadaptation: the role of osmolytes in bacterial stress and virulence. Fems Microbiology Reviews 26, 49-71, https://doi.org/10.1111/j.1574-6976.2002.tb00598.x (2002).

12. Brown, A. D. Microbial water stress. Bacteriological Reviews 40, 803-846 (1976).

13. Brown, A. D. Advances in Microbial Physiology 17, 181-242 (1978).

14. Kempf, B. \& Bremer, E. Uptake and synthesis of compatible solutes as microbial stress responses to high-osmolality environments. Archives of Microbiology 170, 319-330, https://doi.org/10.1007/s002030050649 (1998).

15. Yancey, P. H., Clark, M. E., Hand, S. C., Bowlus, R. D. \& Somero, G. N. Living with water stress: evolution of osmolyte systems. Science 217, 1214-1222, https://doi.org/10.1126/science.7112124 (1982).

16. Fukuchi, S., Yoshimune, K., Wakayama, M., Moriguchi, M. \& Nishikawa, K. Unique amino acid composition of proteins in halophilic bacteria. Journal of Molecular Biology 327, 347-357, https://doi.org/10.1016/s0022-2836(03)00150-5 (2003). 
17. Kennedy, S. P., Ng, W. V., Salzberg, S. L., Hood, L. \& DasSarma, S. Understanding the adaptation of Halobacterium species NRC-1 to its extreme environment through computational analysis of its genome sequence. Genome Research 11, 1641-1650, https://doi. org/10.1101/gr.190201 (2001).

18. Kiraga, J. et al. The relationships between the isoelectric point and: length of proteins, taxonomy and ecology of organisms. Bmc Genomics 8, https://doi.org/10.1186/1471-2164-8-163 (2007).

19. Lanyi, J. K. Salt-dependent properties of proteins from extremely halophilic bacteria. Bacteriological Reviews 38, 272-290 (1974).

20. Madern, D., Ebel, C. \& Zaccai, G. Halophilic adaptation of enzymes. Extremophiles 4, 91-98, https://doi.org/10.1007/s007920050142 (2000).

21. Mevarech, M., Frolow, F. \& Gloss, L. M. Halophilic enzymes: proteins with a grain of salt. Biophysical Chemistry 86, 155-164, https:// doi.org/10.1016/s0301-4622(00)00126-5 (2000).

22. Mongodin, E. F. et al. The genome of Salinibacter ruber: Convergence and gene exchange among hyperhalophilic bacteria and archaea. Proceedings of the National Academy of Sciences of the United States of America 102, 18147-18152, https://doi.org/10.1073/ pnas.0509073102 (2005).

23. Paul, S., Bag, S. K., Das, S., Harvill, E. T. \& Dutta, C. Molecular signature of hypersaline adaptation: insights from genome and proteome composition of halophilic prokaryotes. Genome Biology 9, R70, https://doi.org/10.1186/gb-2008-9-4-r70 (2008).

24. Tadeo, X. et al. Structural basis for the aminoacid composition of proteins from halophilic Archea. Plos Biology 7, e1000257, https:// doi.org/10.1371/journal.pbio.1000257 (2009).

25. Zaccai, G. \& Eisenberg, H. Halophilic proteins and the influence of solvent on protein stabilization. Trends in Biochemical Sciences 15,333-337, https://doi.org/10.1016/0968-0004(90)90068-m (1990).

26. Galinski, E. A. \& Truper, H. G. Microbial behavior in salt-stressed ecosystems. Fems Microbiology Reviews 15, 95-108, https://doi. org/10.1016/0168-6445(94)90106-6 (1994).

27. Imhoff, J. F. \& Rodriguezvalera, F. Betaine is the main compatible solute of halophilic eubacteria. Journal of Bacteriology 160, 478-479 (1984).

28. Deole, R., Challacombe, J., Raiford, D. W. \& Hoff, W. D. An extremely halophilic proteobacterium combines a highly acidic proteome with a low cytoplasmic potassium content. Journal of Biological Chemistry 288, 581-588, https://doi.org/10.1074/jbc. M112.420505 (2013).

29. Youssef, N. H. et al. Trehalose/2-sulfotrehalose biosynthesis and glycine-betaine uptake are widely spread mechanisms for osmoadaptation in the Halobacteriales. ISME J 8, 636-649, https://doi.org/10.1038/ismej.2013.165 (2013).

30. Oren, A., Heldal, M., Norland, S. \& Galinski, E. A. Intracellular ion and organic solute concentrations of the extremely halophilic bacterium Salinibacter ruber. Extremophiles 6, 491-498, https://doi.org/10.1007/s00792-002-0286-3 (2002).

31. Imhoff, J. F. \& Suling, J. The phylogenetic relationship among Ectothiorhodospiraceae: A reevaluation of their taxonomy on the basis of 16S rDNA analyses. Archives of Microbiology 165, 106-113, https://doi.org/10.1007/s002030050304 (1996).

32. Raymond, J. C. \& Sistrom, W. R. Ectothiorhodospira halophila - A new species of genus Ectothiorhodospira. Archiv Fur Mikrobiologie 69, 121-126, https://doi.org/10.1007/bf00409756 (1969).

33. Imhoff, J. F. \& Truper, H. G. Ectothiorhodospira halochloris sp. nov. new extremely halophilic phototrophic bacterium containing bacteriochlorophyll B. Archives of Microbiology 114, 115-121, https://doi.org/10.1007/bf00410772 (1977).

34. Galinski, E. A. \& Truper, H. G. Betaine, a compatible solute in the extremely halophilic phototrophic bacterium Ectothiorhodospira halochloris. Fems Microbiology Letters 13, 357-360, https://doi.org/10.1111/j.1574-6968.1982.tb08287.x (1982)

35. Gavlak, R., Horneck, D., Miller, R. O. \& Kotuby-Amacher, J. Soil, Plant and Water Reference Methods for the Western Region, 2nd edn. WCC-103 Publication, Colorado State University, Ft. Collins, Colorado, USA (2003).

36. Zimmermann, U., Pilwat, G. \& Gunther, T. Regulation of intracellular potassium concentration in Escherichia coli B525. Biochimica Et Biophysica Acta 311, 442-451, https://doi.org/10.1016/0005-2736(73)90324-6 (1973).

37. Bessieres, M. A., Gibon, Y., Lefeuvre, J. C. \& Larher, F. A single-step purification for glycine betaine determination in plant extracts by isocratic HPLC. Journal of Agricultural and Food Chemistry 47, 3718-3722, https://doi.org/10.1021/jf990031h (1999).

38. Valadez-Bustos, M. G. et al. A reliable method for spectrophotometric determination of glycine betaine in cell suspension and other systems. Analytical Biochemistry 498, 47-52, https://doi.org/10.1016/j.ab.2015.12.015 (2016).

39. Strahl, H. \& Greie, J. C. The extremely halophilic archaeon Halobacterium salinarum R1 responds to potassium limitation by expression of the $\mathrm{K}+$-transporting KdpFABC P-type ATPase and by a decrease in intracellular $\mathrm{K}+$. Extremophiles 12, 741-752, https://doi.org/10.1007/s00792-008-0177-3 (2008).

40. Challacombe, J. F. et al. Complete genome sequence of Halorhodospira halophila SL1. Standards in Genomic. Sciences 8, 206-214, https://doi.org/10.4056/sigs.3677284 (2013).

41. Styrvold, O. B. et al. Selection, mapping, and characterization of osmoregulatory mutants of Escherichia coli blocked in the cholineglycine betaine pathway. Journal of Bacteriology 165, 856-863, https://doi.org/10.1128/jb.165.3.856-863.1986 (1986).

42. Hoffmann, T. \& Bremer, E. Guardians in a stressful world: The Opu family of compatible solute transporters from Bacillus subtilis. Biological Chemistry 398, 193-214, https://doi.org/10.1515/hsz-2016-0265 (2017).

43. Kappes, R. M. et al. Two evolutionarily closely related ABC transporters mediate the uptake of choline for synthesis of the osmoprotectant glycine betaine in Bacillus subtilis. Molecular Microbiology 32, 203-216, https://doi. org/10.1046/j.1365-2958.1999.01354.x (1999).

44. Deshnium, P., Los, D. A., Hayashi, H., Mustardy, L. \& Murata, N. Transformation of Synechococcus with a gene for choline oxidase enhances tolerance to salt stress. Plant Molecular Biology 29, 897-907, https://doi.org/10.1007/BF00014964 (1995).

45. Rozwadowski, K. L., Khachatourians, G. G. \& Selvaraj, G. Choline oxidase, a catabolic enzyme in Arthrobacter pascens, facilitates adaptation to osmotic stress in Escherichia coli. Journal of Bacteriology 173, 472-478, https://doi.org/10.1128/jb.173.2.472-478.1991 (1991).

46. Csonka, L. N. \& Hanson, A. D. Annual Review of Microbiology 45, 569-606 (1991).

47. Boch, J., Kempf, B., Schmid, R. \& Bremer, E. Synthesis of the osmoprotectant glycine betaine in Bacillus subtilis: Characterization of the gbsAB genes. Journal of Bacteriology 178, 5121-5129, https://doi.org/10.1128/jb.178.17.5121-5129.1996 (1996).

48. Nyyssölä, A., Kerovuo, J., Kaukinen, P., von Weymarn, N. \& Reinikainen, T. Extreme halophiles synthesize betaine from glycine by methylation. Journal of Biological Chemistry 275, 22196-22201, https://doi.org/10.1074/jbc.M910111199 (2000).

49. Ziegler, C., Bremer, E. \& Krämer, R. The BCCT family of carriers: From physiology to crystal structure. Molecular Microbiology 78, 13-34, https://doi.org/10.1111/j.1365-2958.2010.07332.x (2010).

50. Sand, M. et al. Salt adaptation in Acinetobacter baylyi: Identification and characterization of a secondary glycine betaine transporter. Archives of Microbiology 193, 723-730, https://doi.org/10.1007/s00203-011-0713-x (2011).

51. Nyyssölä, A. \& Leisola, M. Actinopolyspora halophila has two separate pathways for betaine synthesis. Archives of Microbiology 176, 294-300, https://doi.org/10.1007/s002030100325 (2001)

52. Kappes, R. M., Kempf, B. \& Bremer, E. Three transport systems for the osmoprotectant glycine betaine operate in Bacillus subtilis: Characterization of OpuD. Journal of Bacteriology 178, 5071-5079, https://doi.org/10.1128/jb.178.17.5071-5079.1996 (1996).

53. Imhoff, J. F., Hashwa, F. \& Truper, H. G. Isolation of extremely halophilic phototrophic bacteria from the alkaline Wadi Natrun, Egypt. Archiv Fur Hydrobiologie 84, 381-388 (1978).

54. Ollivier, B., Caumette, P., Garcia, J. L. \& Mah, R. A. Anaerobic bacteria from hypersaline environments. Microbiological Reviews 58, 27-38 (1994) 
55. Fischel, U. \& Oren, A. Fate of compatible solutes during dilution stress in Ectothiorhodospira marismortu. Fems Microbiology Letters 113, 113-118 (1993).

56. Tschichholz, I. \& Truper, H. G. Fate of compatible solutes during dilution stress in Ectothiorhodospira halochloris. Fems Microbiology Ecology 73, 181-185, https://doi.org/10.1111/j.1574-6968.1990.tb03939.x (1990).

57. Peters, P., Telor, E. \& Truper, H. G. Transport of glycine betaine in the extremely haloalkaliphilic sulfur bacterium Ectothiorhodospira halochloris. Journal of General Microbiology 138, 1993-1998 (1992).

58. Bremer, E. \& Krämer, R. Responses of Microorganisms to Osmotic Stress. Annu Rev Microbiol 73, 313-334 (2019).

59. Imhoff, J. F., Sahl, H. G., Soliman, G. S. H. \& Truper, H. G. Wadi Natrun: chemical composition and microbial mass developments in alkaline brines of eutrophic desert lakes. Geomicrobiology Journal 1, 219-234 (1979).

60. Lai, M. C. \& Gunsalus, R. P. Glycine betaine and potassium ions are the major compatible solutes in the extremely halophilic methanogen Methanohalophilus strain Z7302. Journal of Bacteriology 174, 7474-7477 (1992).

61. Desmarais, D., Jablonski, P. E., Fedarko, N. S. \& Roberts, M. F. 2-sulfotrehalose, a novel osmolyte in haloalkaliphilic archaea. Journal of Bacteriology 179, 3146-3153 (1997).

62. Galinski, E. A. \& Herzog, R. M. The role of trehalose as a substitute for nitrogen-containing compatible solutes (Ectothiorhodospira halochloris). Archives of Microbiology 153, 607-613, https://doi.org/10.1007/bf00245273 (1990).

63. Saum, S. H. \& Muller, V. Salinity-dependent switching of osmolyte strategies in a moderately halophilic bacterium: Glutamate induces proline biosynthesis in Halobacillus halophilus. Journal of Bacteriology 189, 6968-6975, https://doi.org/10.1128/jb.00775-07 (2007).

64. Saum, S. H. \& Muller, V. Growth phase-dependent switch in osmolyte strategy in a moderate halophile: ectoine is a minor osmolyte but major stationary phase solute in Halobacillus halophilus. Environmental Microbiology 10, 716-726, https://doi. org/10.1111/j.1462-2920.2007.01494.x (2008).

65. Kokoeva, M. V., Storch, K. F., Klein, C. \& Oesterhelt, D. A novel mode of sensory transduction in archaea: Binding protein-mediated chemotaxis towards osmoprotectants and amino acids. EMBO Journal 21, 2312-2322, https://doi.org/10.1093/emboj/21.10.2312 (2002).

\section{Acknowledgements}

We thank Professor Noha Youssef and Professor Mostafa Elshahed for valuable discussions.

\section{Author contributions}

R.D. performed the experiments and bioinformatics analyses, analyzed data, and wrote the paper. W.D.H. designed the research, analyzed and interpreted data, and wrote the paper.

\section{Competing interests}

The authors declare no competing interests.

\section{Additional information}

Supplementary information is available for this paper at https://doi.org/10.1038/s41598-020-59231-9.

Correspondence and requests for materials should be addressed to W.D.H.

Reprints and permissions information is available at www.nature.com/reprints.

Publisher's note Springer Nature remains neutral with regard to jurisdictional claims in published maps and institutional affiliations.

Open Access This article is licensed under a Creative Commons Attribution 4.0 International License, which permits use, sharing, adaptation, distribution and reproduction in any medium or format, as long as you give appropriate credit to the original author(s) and the source, provide a link to the Creative Commons license, and indicate if changes were made. The images or other third party material in this article are included in the article's Creative Commons license, unless indicated otherwise in a credit line to the material. If material is not included in the article's Creative Commons license and your intended use is not permitted by statutory regulation or exceeds the permitted use, you will need to obtain permission directly from the copyright holder. To view a copy of this license, visit http://creativecommons.org/licenses/by/4.0/.

(C) The Author(s) 2020 